\title{
Cloud-to-ground flash patterns for Atlanta, Georgia (USA) from 1992 to 2003
}

\author{
J. Anthony Stallins ${ }^{1, *}$, Mace L. Bentley ${ }^{2}$, Leanna S. Rose ${ }^{1}$ \\ ${ }^{1}$ Department of Geography, Florida State University, Rm 323, Bellamy Building, Tallahassee, Florida 32303-2190, USA \\ ${ }^{2}$ Department of Geography, Northern Illinois University, Rm 118, Davis Hall, Dekalb, Illinois 60115-2895, USA
}

\begin{abstract}
We analyzed the patterns of cloud-to-ground (CG) lightning flashes around Atlanta Georgia (USA), a region that has undergone an intense conversion from natural to anthropogenic land uses. For the 12 yr period from 1992 to 2003, annual average CG flash densities of 6 to 8 flashes km-2 emerged around Atlanta. These values are 50 to $75 \%$ higher than in the surrounding rural areas, and comparable to flash densities along the Atlantic coast of Georgia. High flash densities extended over a large swath of Atlanta, and into Gwinnett County, a heavily suburbanized, rapidly growing county to the northeast. Urban flash production peaked during the summer (May through June) and exhibited more night and early morning activity (18:00 to 06:00 h) than in surrounding rural areas. Atlanta's higher flash densities do not result from isolated flash production over the city; rather they develop when the large scale atmospheric setting favors widespread lightning throughout the region. Maps of flash counts by interval classes also revealed where flash density maxima emerge in different county regions around the city. A large area of reduced positive polarity flashes developed along the arc of Atlanta's loop highway, Interstate 285. This area also trended south along the corridor of Interstate Highway 75 into central Georgia. This pattern suggests that automobiles may be a source of particulate matter, which is hypothesized to reduce the percentage of positive flashes.
\end{abstract}

KEY WORDS: Lightning · Urban heat island · Air pollution · GIS · Hazard assessment Resale or republication not permitted without written consent of the publisher

\section{INTRODUCTION}

Changes from natural to anthropogenic land cover can have a marked impact on local weather and climate (Pielke 2002, Kalnay \& Cai 2003, Marshall et al. 2004). Urban heat islands (UHIs) are one example of this (Oke 1973, Arnfield 2003), as they modify convective processes and precipitation patterns (Huff \& Changnon 1973, Diem \& Brown 2003). The number of days in which thunder occurs increases in the vicinity of cities (Changnon 2001). Since the advent of lightning detection systems, areas of cloud-to-ground (CG) flash augmentation have been observed within and around large urban areas (Wescott 1995, Steiger et al. 2002).

We examined the extent of urban lightning modification around Atlanta, Georgia, a sprawling urban region in the SE USA. Over the last 3 decades, the north-central area of Georgia has undergone intensive and extended land-use transformation. For a 13-county region around the Atlanta city center, low-density urban land use increased from 76910 to 282959 ha (268\%) between 1973 and 1999, largely at the expense of forest and rural acreage (Fig. 1; Lo \& Yang 2002). The Atlanta metropolitan statistical area, now recognized as extending over a 28 county region, had 4.2 million inhabitants in 2000 (Fig. 2; ARC 2003). Consequently, Atlanta and its environs have developed a prominent UHI with accompanying increases in atmospheric pollutants (Quattrochi et al. 1998, Mullen 1999). In 2004, the Environmental Protection Agency cited 20 Atlanta-area counties for ongoing failures to meet air quality standards for particulate matter. Urban heating and particulate matter are linked to changes in the distribution and polarity of CG flash production (Orville et al. 2001, Soriano \& de Pablo 2002, Naccarato et al. 2003).

Although urban flash modification is a wellestablished phenomenon, Atlanta flash patterns have not been assessed over the last decade of urban 


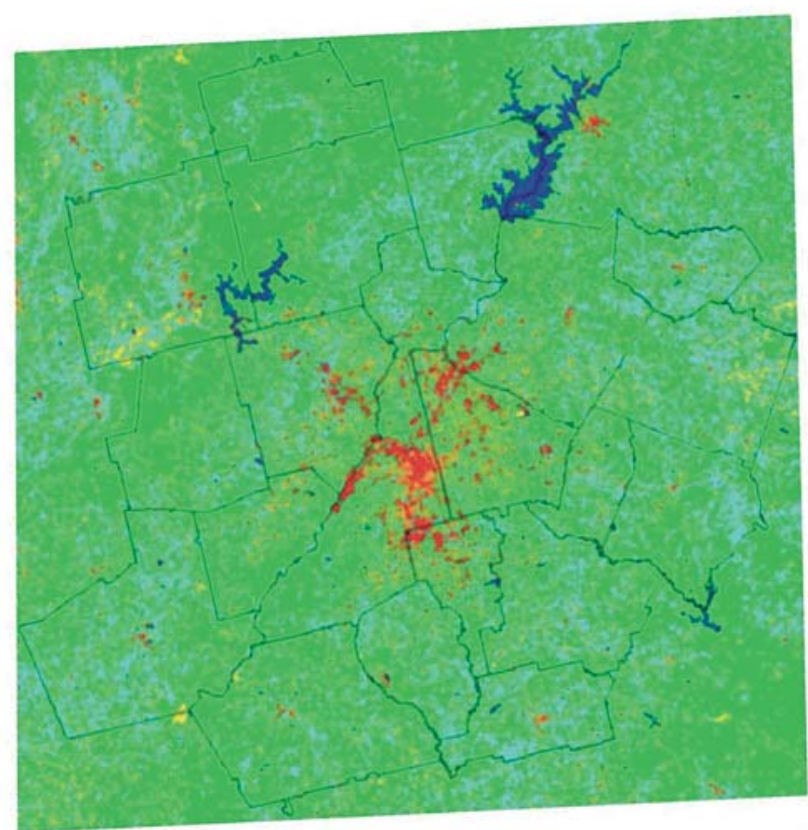

1973

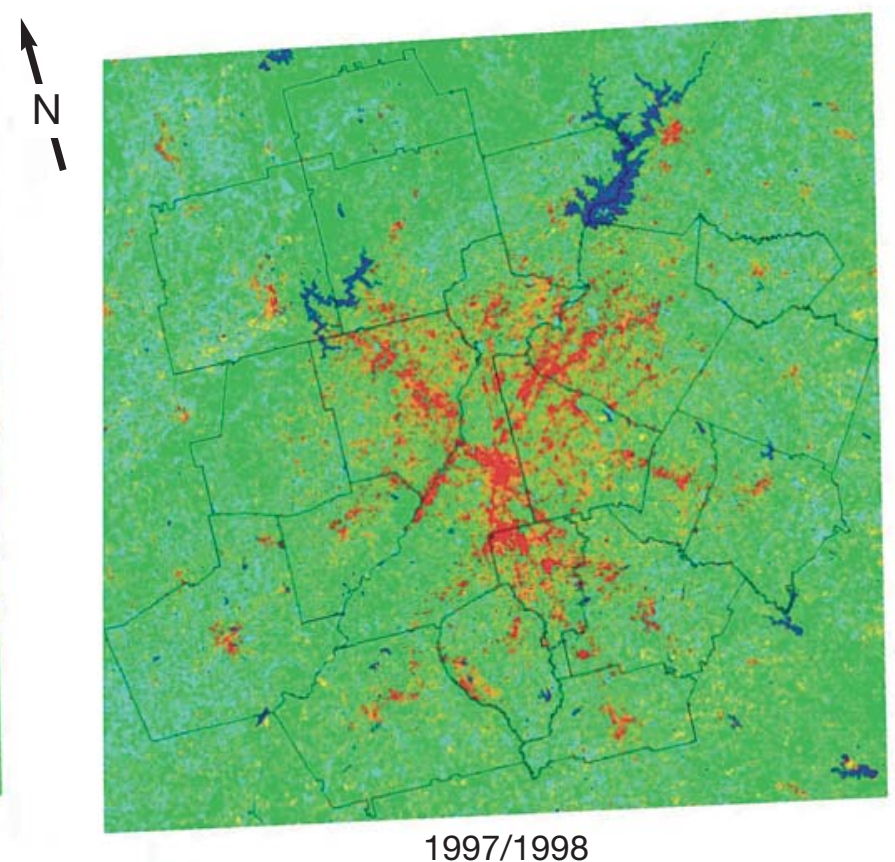

$1997 / 1998$

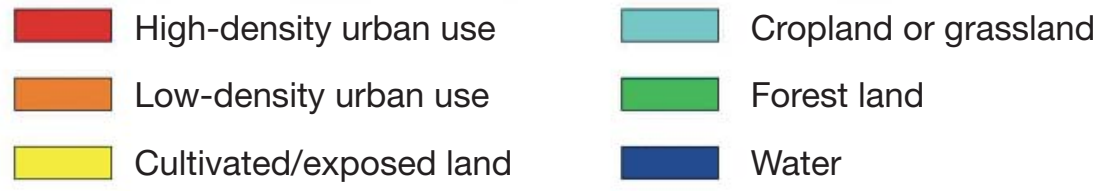

Fig. 1. Changes in land use in the Atlanta region (after Yand \& Lo 2002)

growth. In this study, we mapped seasonal and diurnal flash characteristics for the Atlanta region for the period 1992-2003 and examined 2 questions common to urban lightning studies: (1) Are areas of greater CG flash occurrence the result of an increase in the number of days when flashes are observed, or the result of enhanced flash production? (2) To what extent do days with large versus small total flash counts contribute to this augmentation?

\section{BACKGROUND}

Urban-modified CG flash characteristics occur in cities at various latitudes, from the tropics (São Paulo, Brazil; Naccarato et al. 2003) to the Midwest USA (Westcott 1995). Flash distributions in these cities, as well as for cities along the northern Gulf of Mexico (Orville et al. 2001, Steiger \& Orville 2003), the Iberian peninsula (Areitio et al. 2001, Soriano \& de Pablo 2002) and Brazil (Pinto et al. 2004) are sufficiently documented to conclude that the atmospheric properties of urban areas have the propensity to alter CG flash densities. Although the methods and the spatial and temporal extent of flash observations vary among studies, differences in flash density between urban and rural areas can attain 136\% (St. Louis, Missouri; Wescott 1995) to 150-200\% (Naccarato et al. 2003). In most cities, flash augmentation develops over the central urban core, or up to $100 \mathrm{~km}$ or more downwind (Naccarato et al. 2003). Urban areas have a lower percentage of positive polarity CG flashes, and for some locations, decreased total (positive and negative) CG flash production (Westcott 1995, Orville et al. 2001).

The urban modification of lightning is theorized to develop from many of the same processes that influence precipitation in the vicinity of large cities. Urban areas can modify convection and precipitation through dynamic forcing mechanisms initiated by thermal properties of the UHI and the topography of the built environment (Changnon et al. 1976, Bornstein \& Lin 2000). Modeling has shown that urban surface roughness, greater sensible heat flux, and complex local wind patterns of UHI-impacted regions may synergistically enhance the formation of updrafts complementary to thunderstorm development (Baik et al. 2001, Rozoff et al. 2003). However, to initiate cloud electrification in a developing thunderstorm, supercooled liquid water, graupel (soft hail) and ice are required. Collisions among these hydrometeors and mixed- 


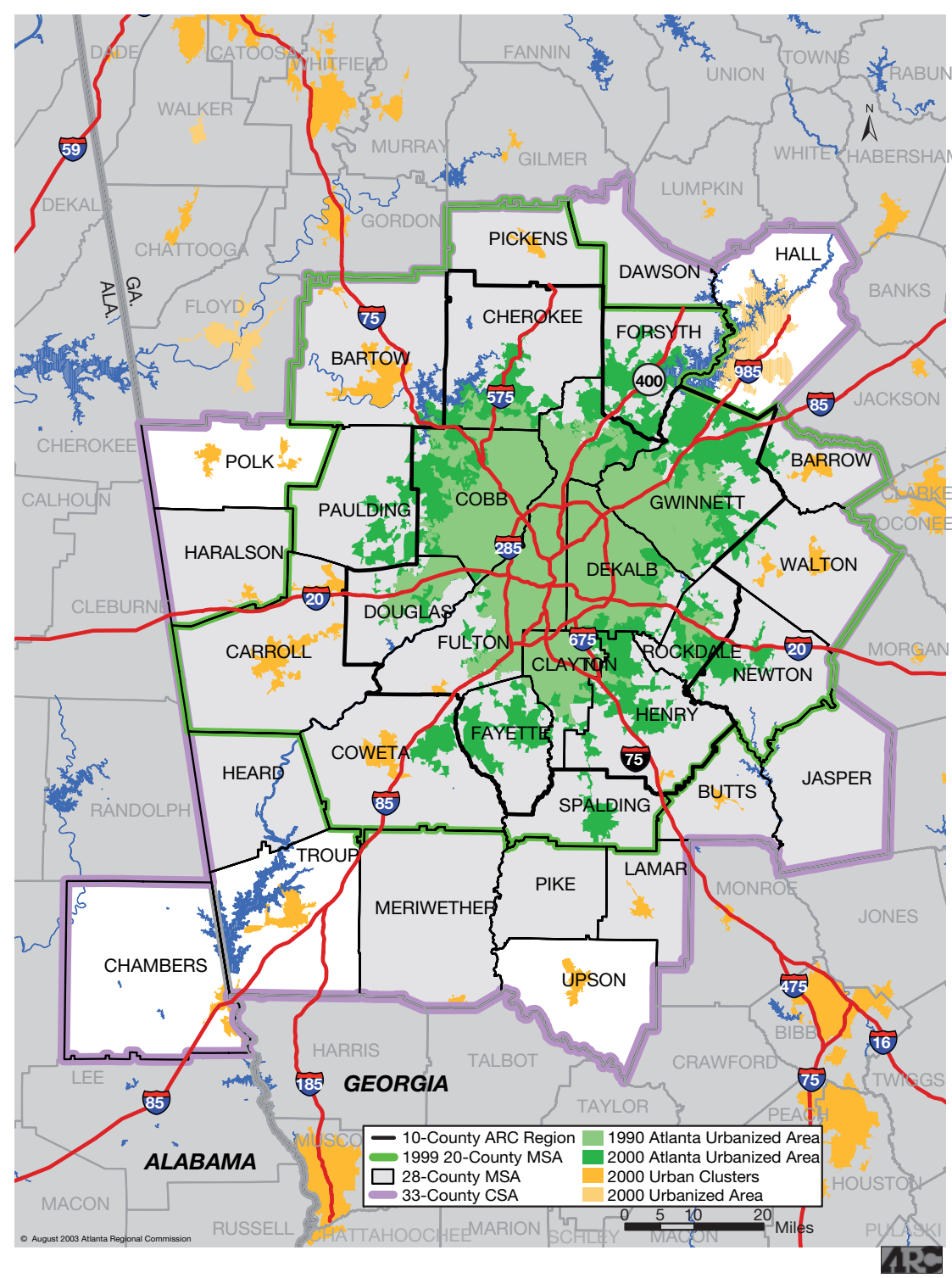

Fig. 2. Atlanta, Georgia, USA: Metropolitan Statistical Area (MSA) and Combined Statistical Area (CSA) as recognized by the U.S. Census (from ARC 2003). Interstate highway nos. are marked

phase microphysical dynamics promote the movement and polarization of charges that give rise to lightning flashes. This natural lightning production mechanism is known as noninductive charge separation (MacGorman \& Rust 1998, Seity et al. 2003), and it depends upon the amount of supercooled water (Saunders 1993). With increased convective available potential energy from urban heat, more water droplets may be transported above the freezing level, leading to the enhanced polarization of cloud electrical charges, and enhanced flash production (Steiger et al. 2002).

The noninductive charge separation process may also be sensitive to anthropogenic aerosols, which have a propensity to function as cloud condensation nuclei and can thus alter interactions among hydrometeors, resulting in an enhancement of lightning production (Rosenfeld \& Lensky 1998, Orville et al. 2001). Higher concentrations of cloud condensation nuclei reduce the mean size of cloud droplets, and this may decrease droplet collision efficiency and weaken the coalescence processes leading to rainfall (see Givati \& Rosenfeld 2004). Delay in rain postpones the formation of downdrafts, allowing for more vigorous updrafts and deeper and stronger lightning production. Increased CG flash densities around São Paulo, Brazil, and surrounding cities were positively correlated with particulate matter $<10 \mu \mathrm{m}$ in diameter $\left(\mathrm{PM}_{10}\right.$; Naccarato et al. 2003). A similar correspondence between flash den- 
sities and aerosol concentrations was observed east (downwind) of Houston, Texas (Steiger et al. 2002). High flash densities around Lake Charles, Louisiana, were attributed to aerosol production from local oil and chemical-refining industries (Steiger \& Orville 2003) .

These dynamics have been formulated as the Rosenfeld-Lensky hypothesis (Rosenfeld \& Lensky 1998). When droplets are too small to fall out of a cloud, they are instead transported to higher levels in the atmosphere. This suppresses precipitation and increases the quantity of supercooled water at greater heights, resulting in the formation of more graupel, more collisions between ice particles, and enhanced charge polarization and flash production. Thus, according to the Rosenfeld-Lensky Hypothesis, the initial suppression of precipitation due to aerosols ultimately constitutes an additional mechanism by which the UHI enhances lightning (Shepherd in press).

Aerosols also alter the percentage of positive flashes, which are negatively correlated to $\mathrm{PM}_{10}$ levels (Naccarato et al. 2003). Regions with decreased positive flashes ( -20 to $-24 \%)$ occur in the vicinity of aerosolemitting industrial sectors of Texas and Louisiana (Steiger et al. 2002, Steiger \& Orville 2003). The mechanism for aerosol-induced reductions in positive flashes is not well understood. In a typical thunderstorm, negatively charged graupel migrates to the base of the cloud, while positive charges attached to smaller ice particles rise towards the top. The delay in downdrafts attributed to aerosols may lead to a greater accumulation of positive charges in the top of the cloud, thereby reducing the number of positive flashes lowered to the ground. Steiger et al. (2002) provide a review of the microphysical mechanisms and cloud charge distributions theorized to reduce (and in some cases, increase) positive flashes.

Along with increased interest in the processes of urban thunderstorm electrification, there has been a renewed focus on the subtleties of flash patterns (Steiger et al. 2002, Gauthier et al. 2005). Although urban flash augmentation is a well-recognized phenomenon, less is known about the flash intensities and thunderstorm frequencies which produce it. For the cities studied by Steiger et al. (2002) and Wescott (1995), large flash-producing thunderstorm events contributed more to flash augmentation. However, multiyear lightning data sets may require more nuanced analyses to resolve these patterns (Gauthier et al. 2005). These refinements should in turn facilitate inferences about the underlying processes. In this study, we describe the spatial and temporal patterns of CG flash modification around Atlanta, Georgia. We evaluated whether any observed augmentation was the result of increased flash production, or of an increase in the number of days when flashes occur. We also documented the extent to which large or small lightning day events (defined by the number of flashes produced on a given day) contribute to flash augmentation. Our study is novel in that we map flashes by classes defined according to the total amount of $\mathrm{CG}$ lightning produced. Our results show that flash density distributions change with total flash production, a correlate of atmospheric stability. From these findings, we make inferences about urban flash initiation mechanisms and discuss methods for delineating urban versus non-urban flash production.

\section{METHODS}

\subsection{Study Area}

The city of Atlanta $\left(33.76^{\circ} \mathrm{N}, 84.4^{\circ} \mathrm{W}\right)$ is located in the Georgia Piedmont at an elevation of $320 \mathrm{~m}$ above sea level (Fig. 3). The Atlanta UHI has the propensity to alter convective processes and the initiation and location of precipitation (Bornstein \& Lin 2000, Craig \& Bornstein 2002, Shepherd et al. 2002, Dixon \& Mote 2003, Diem \& Mote 2005). Two studies of lightning, conducted as part of hazard assessments before the Olympic Games held in Atlanta in 1996 (Livingston et al. 1996, Watson \& Holle 1996), found several isolated maxima in flash density $\left(<3\right.$ flashes $\left.\mathrm{km}^{-2} \mathrm{mo}^{-1}\right)$ around Atlanta for summer months between 1986 and 1993.

Atlanta was selected for this study based on its geographic location and its potential sensitivity to weather hazards. Atlanta's inland location sets it apart from Tampa and Orlando, Forida, which also have high thunderstorm frequencies and urban land-uses. UHI effects in Florida coastal cities are modified by coastal land and sea breeze convergence zones, a factor that also complicates urban flash patterns in Houston, Texas (Steiger et al. 2002, Gather et al. 2005). Lightning is an often overlooked cause of property losses in Georgia (Stallins 2002) and any enhancement of flashes in the Atlanta area would be of interest to insurers, planners, and fire departments. Although the weather loss records published by the National Climatic Data Center in their online archive 'Storm Data' underestimate dollar losses (Currant et al. 2000), it is still useful for illustrating the extent of urban lightning property losses. For the year 2000, 7 Atlanta metro counties accrued $\$ 4.8$ million (approximately $60 \%$ of the total statewide lightning property damage losses of $\$ 7.9$ million). One $3.5 \mathrm{~h}$ thunderstorm in Gwinnett County on the morning of September 21, 2000, resulted in $\$ 625000$ in property damage and $>97$ fire-related calls to county emergency services. As the 'Storm Data' archive bases property loss totals on newspaper reports, the true figures are likely to be considerably higher (Stallins 2002). 


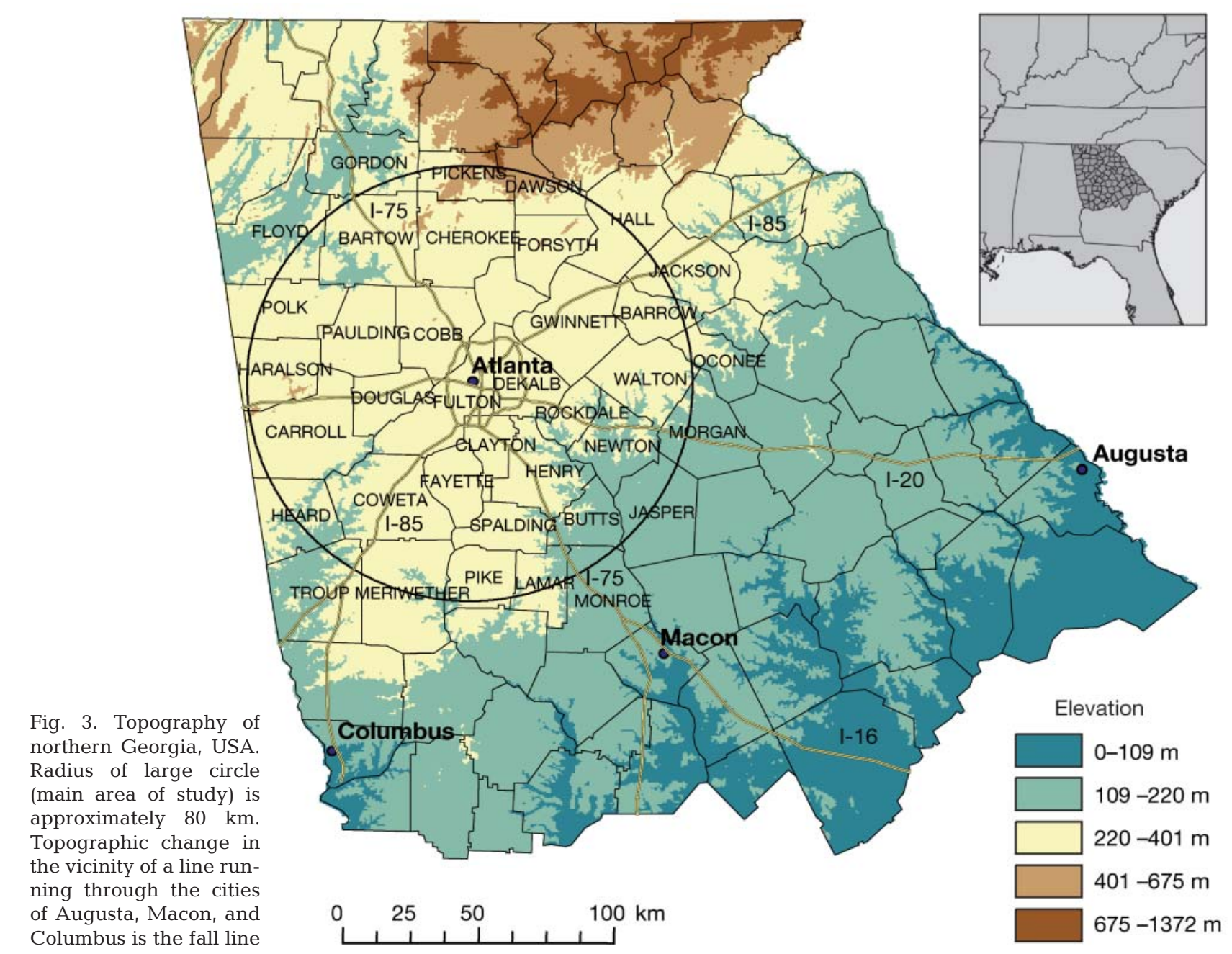

Atlanta's wind regime and the direction of urban and suburban growth were expected to influence the patterns of flash production. The predominant thunderstorm-steering winds for this latitude are found at $700 \mathrm{hPa}$. Average wind direction (May to September) for these mid-level winds is $273^{\circ}$ (Shepherd et al. 2002). Prevailing surface winds originate from the northwest (Weber et al. 2001). The surface wind regime in Atlanta is also influenced by northeasterly winds associated with cold-air damming along the Appalachian Mountains, and cyclonic southerly flow from the Atlantic and Gulf of Mexico. The Atlanta UHI is multinodal, due to the development of satellite cities on its periphery, a common feature of large urban areas (Stone \& Rodgers 2001, Yang \& Lo 2002). A large area of heating develops around Atlanta's main business district in central Fulton County. Peripheral heating nodes are associated with Hartsfield-Jackson Atlanta International Airport in southern Fulton County, and with sprawling urban and suburban corridors in the outlying counties of Gwinnett and Cobb.

\subsection{Analyses}

Flash data for the state of Georgia were obtained from the U.S. National Lightning Detection Network (NLDN; Vaisala) for the years 1992-2003. Upgrades to the network in 1994 resulted in a CG flash detection efficiency of approximately $90 \%$ and a median location accuracy of $500 \mathrm{~m}$ (Cummins et al. 1998). Prior to 1995, CG flash detection efficiency was $70 \%$ with an accuracy of 5 to $10 \mathrm{~km}$. Several flash studies (Orville et al. 2001, Orville \& Huffines 2001, Steiger \& Orville 2003) mapped pre-1995 NLDN data without adjustment for the lowered detection efficiences, a practice we follow in this study as well. The upgrade to the system also resulted in the detection of low current, positive cloud-to-cloud flashes. As recommended by Cummins et al. (1998) positive flashes <10 kA were deleted from the dataset. Flash density was initially mapped at the state level, to establish the spatial extent for smaller-scale analyses of flash variability, seasonal and diurnal production, and percentage of positive flashes. 
To see if flash augmentation is the result of small or large flash-producing events, flash production intervals were mapped for an $80 \mathrm{~km}$ radius around Atlanta. This distance includes a range of flash densities spanning urban and rural flash signatures. Larger areas would have encompassed zones of augmentation that are less likely be solely attributable to urban effects. Smaller areas would have left out the surrounding matrix of lowered flash densities upon which urban enhancement was superimposed. Each calendar day with $\geq 1$ flash within this $80 \mathrm{~km}$ radius was classified into one of 5 exponentially ranked intervals: 1-10, 11-100, 101-1000, 1001-10 000, and $>10000$ flashes $d^{-1}$ (see Steiger et al. 2002). CG flash production in thunderstorms is best described by an exponential distribution, because large storms produce several orders of magnitude more flashes than smaller storms. By analyzing the spatial patterns of flashes within each interval, any urban enhancement occurring on days with high total flash production can be discriminated from the contribution of days with low production. Flashes for each interval were additionally sampled within 3 smaller circular zones (20 km radius) of high urban flash density (see Figs. 9 \& 10). By visualizing when and where high flash densities developed, we were able to infer additional detail about the mechanisms underlying urban flash enhancement.

A similar technique was employed to document whether there was a greater number of flash days, or higher flash production, in areas where urban augmentation was detected. On a map showing the number of flash days observed in each grid cell, positioned over 3 circular zones were areas that exhibited marked contrasts in the number of flash days. For each zone, we calculated the number of shared flash days (observed in both of the other sample areas) and unique flash days (not observed in any other sample), and the respective number of flashes produced. The nonparametric version of a paired sampled $t$-test, the Wilcoxon signed-rank sum test $\left(\mathrm{Z}_{\mathrm{w}}\right)$, was used to test for significant differences in interval flash counts and shared day flash counts for pairs of circular zones. This assessed the magnitude of the differences in flash counts as well as the direction (sign) of these differences. All statistical tests were conducted at the 0.05 significance level.

Flash data were mapped in their original format; no smoothing or estimator-based algorithms were used. All flash data were gridded at a resolution of $2 \times 2 \mathrm{~km}$ in ArcGIS 9.0 (ESRI 2004). A small grid size relative to the median flash location accuracy permitted a higher resolution of patterns. Over large spatial extents, this grid cell size also lessens the likelihood of interpretative overgeneralization at the expense of local varia- bility. For instance, high flash activity was observed within a single $2 \times 2 \mathrm{~km}$ cell corresponding to Pine Log Mountain, an isolated ridgetop in Bartow County NW of Atlanta. In some cases, these maxima were rescaled to the next lower value so as to facilitate visualization of flash patterns.

\section{RESULTS}

CG flash enhancement around Atlanta was visible at the state level (Fig. 4). Urban flash densities were greatest over Atlanta, and to the NE (Gwinnett County) and SW (Coweta County). Flash density was 6-8 flashes $\mathrm{km}^{-2} \mathrm{yr}^{-1}$, as high as observed along the Atlantic coast. Areas of higher flash density also occurred in NW Georgia (Bartow County) and in central eastern Georgia. Lower relative flash densities were observed west and SW of Atlanta, and in the NE corner of the state. The area of reduced flash density SW of Atlanta coincides with a low precipitation anomaly identified by Shepherd et al. (2002). The low flash densities in the NE corner of the state can be attributed to the prevailing westerly airflow across the SW-NE axis of the Appalachian Mountains, which generates downslope wind movement, thereby suppressing convection and thunderstorm formation. Statewide flash distribution is discussed in Bentley \& Stallins (2005).

The location of flash peaks within $80 \mathrm{~km}$ of the city center was variable from year to year (Fig. 5). In some years, urban flash hotspots were absent, or developed at different positions relative to the Atlanta city center. However, annual standard deviation (SD) of flash density within the Atlanta region was lower and more diffusely distributed, compared to the maxima in SD outside Atlanta (Fig. 6). Flash production was low in fall and winter, comprising only $10 \%$ of the total. Urban augmentation emerged during the spring (March-May), although overall flash densities were still relatively low (Fig. 7), and production peaked during the summer (June-August). Most flashes occurred between 18:00 and 24:00 h local standard time (LST). While activity over the region declined between 24:00 and 06:00 h LST, enhanced flash production was still apparent around Atlanta.

A large region with fewer positive flashes developed over and downwind (east) of Atlanta (Fig. 8), along the arc of Interstate 285, Atlanta's perimeter highway. This zone of reduced positive flashes extends slightly north and to the south, near Interstate 75, a major north-south transportation corridor that extends into Florida.

Three zones of enhanced flash density, trending NE to $\mathrm{SW}$, developed within the $80 \mathrm{~km}$ radius of the city center (Fig. 9). The NE zone covers Gwinnett County, 
which includes sprawling urban land cover in the west, and suburbs and farmland in the east. Flash densities of 8.0 flashes $\mathrm{km}^{-2} \mathrm{yr}^{-1}$ could be discerned for a few cells in the middle of the county. The Atlanta central city zone of flash enhancement follows the outline of Interstate 285, the loop highway encompassing downtown Atlanta and Hartsfield-Jackson Atlanta International Airport. The SW zone is largely suburban to rural (Coweta County). Flash production was consistent across zones for each flash interval (Table 1).

The spatial patterns of flashes by interval revealed how flash density maxima differentially emerged among the 3 zones of enhancement. On days when flash production was 1-10 or 11-100 flashes, there was little differentiation of urban flash counts across the $80 \mathrm{~km}$ study area (Fig. 10). On days with 101-1000 flashes, higher flash production emerged over the city center, while areas of relatively lower flash production formed a discontinuous ring around the maxima; higher flash densities in the NE and SW zones were not as well developed, and flash counts paired by date

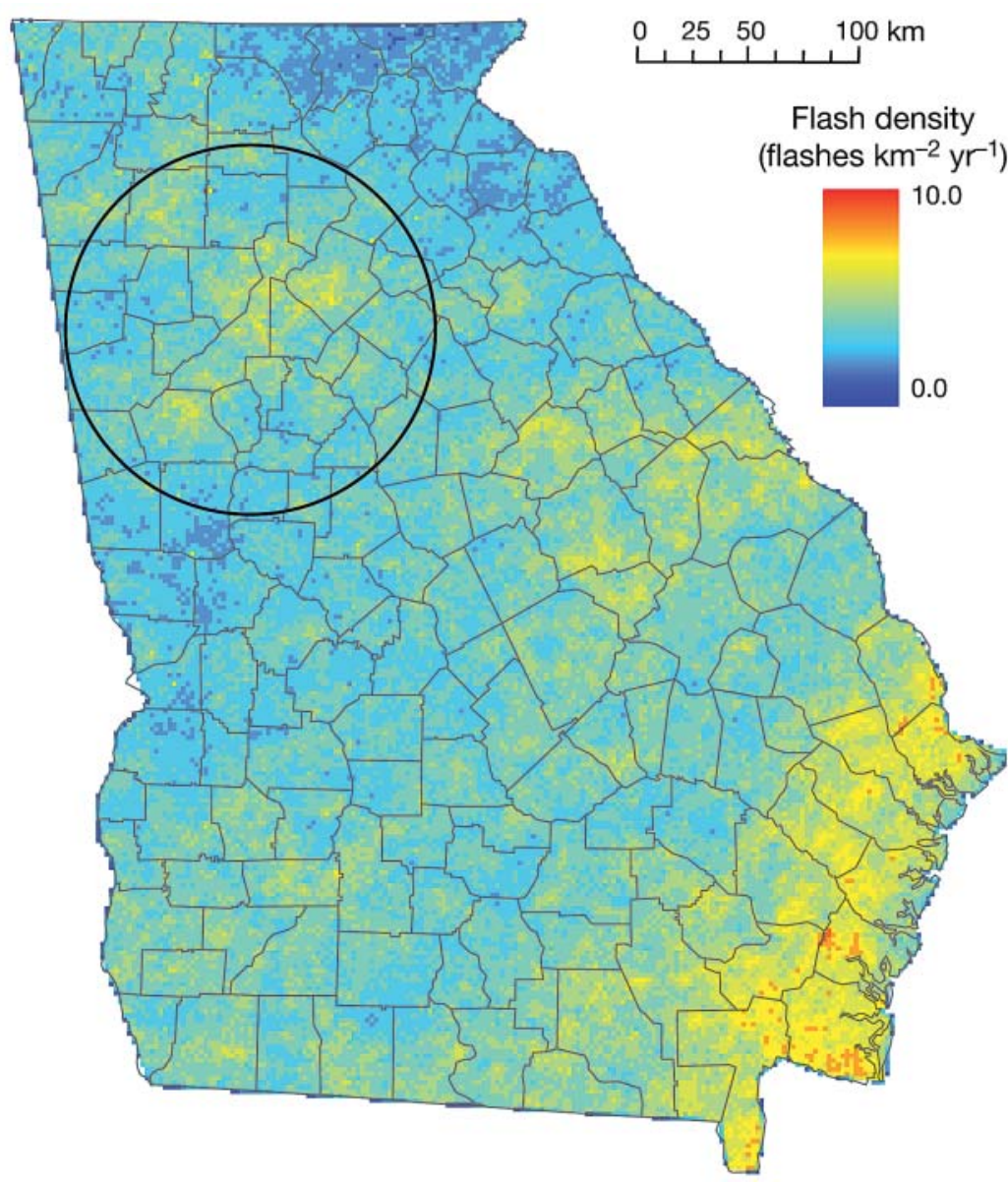

Fig. 4. Annual average flash density for the state of Georgia, USA. Higher flash densities are associated with Atlanta and north Fulton County, Gwinnett County, Bartow County to the north, Coweta County to the southwest, east centra Georgia, and the southeast Atlantic coast. Main Study area is denoted by circle were significantly higher in the central zone than in the NE $\left(Z_{\mathrm{W}}=-1.98, \mathrm{p}=0.047\right)$ and $\mathrm{SW}\left(\mathrm{Z}_{\mathrm{W}}=-2.66, \mathrm{p}=\right.$ $0.008)$ zones. When density for days with 1001-10000 flashes was gridded, the NE and SW zones of flash density enhancement became prominent and the discontinuous ring of lowered flash production retreated outward; flash count distributions for the central city and the NE zone were not statistically distinguishable $\left(Z_{\mathrm{w}}=-0.24, \mathrm{p}=0.810\right)$, but flash counts remained significantly higher across the central city compared to the SW zone $\left(\mathrm{Z}_{\mathrm{w}}=-2.29, \mathrm{p}=0.022\right)$. On days having $>10000$ flashes, urban augmentation was not evident; only 2 such days were observed (in July 1998 and 1999), and flash production followed storm tracks, as might be expected in the case of large thunderstorms.

The number of flash days peaked toward the NE of Atlanta over portions of Fulton, Gwinnett and Cobb counties (Fig. 11). The greatest number of flash days developed in Fulton County's Midtown district, a few kilometers north of the Atlanta city center. Day counts in this area ranged from 142 to $147 \mathrm{~d}$, and were exceeded only by Pine Log Mountain (700 m a.s.l.) in Bartow and Cherokee counties. Two outlying zones (east and south, $20 \mathrm{~km}$ radius) with low flash day counts were demarcated for comparison with the central zone, in order to determine shared and unique flash days. A total of 611 flash days were shared by all 3 zones, comprising most of the total flash production in each zone (88.4 to $92.2 \%$; Table 2). Unique flash days contributed only $11 \%$ of the total strikes for NE Atlanta; however, this zone still maintained significantly higher flash counts than the western $\left(Z_{\mathrm{w}}=-3.50, \mathrm{p}<\right.$ $0.001)$ and southern $\left(Z_{\mathrm{w}}=-4.38, \mathrm{p}<0.001\right)$ zones on shared flash days.

\section{DISCUSSION}

Annual average flash densities around Atlanta are 50 to $75 \%$ higher than in the surrounding rural areas. The distribution of these urban flash density hotspots did not follow a simple upwind-downwind axis. This may be due in part to the variable wind regime of Atlanta, the regional physiography, and contingencies of urban growth and development that determine the geographic position of urban heating nodes. The percentage of positive flashes, however, corresponded more strongly to the predominant upwind-downwind (WNW to E-SE) axis. Reductions in percent 


\section{2}

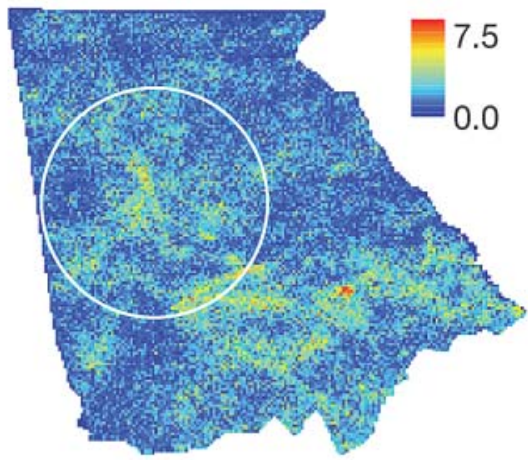

1995

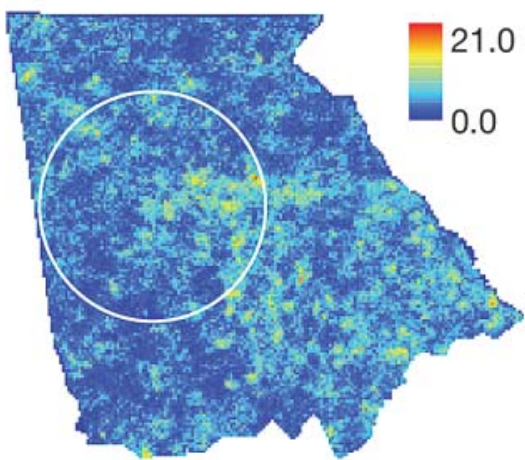

1998

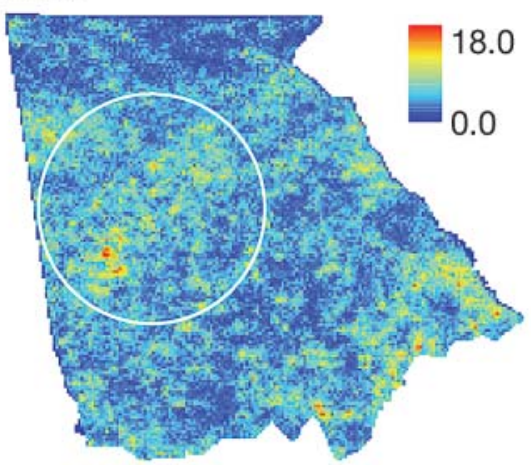

\section{1}

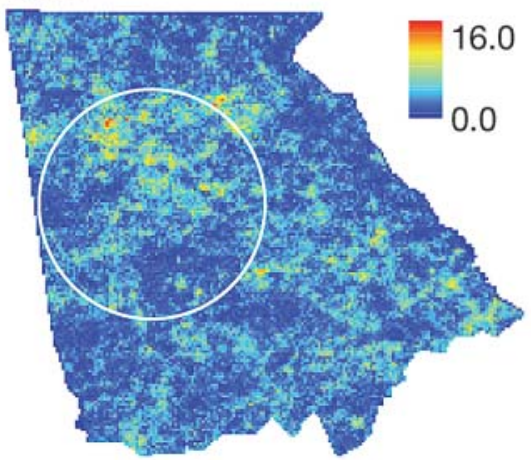

1993

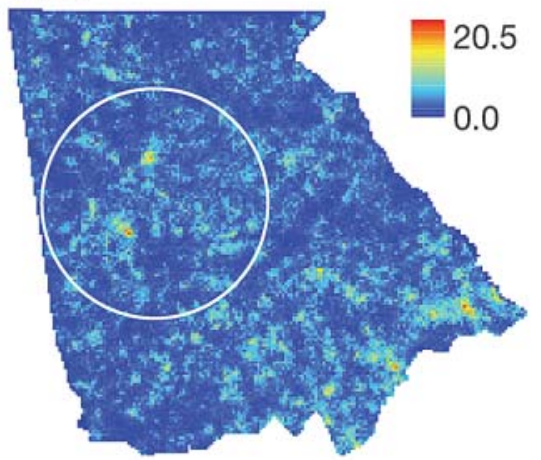

1996

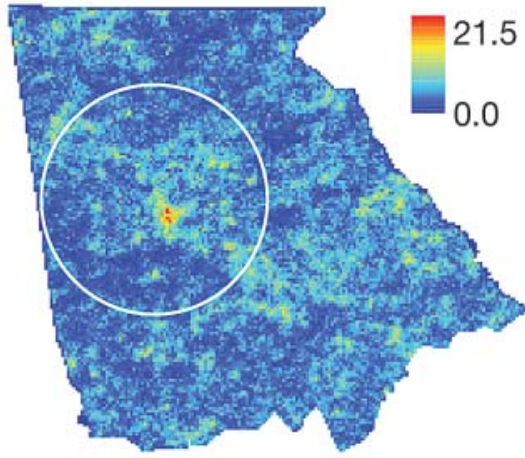

1999

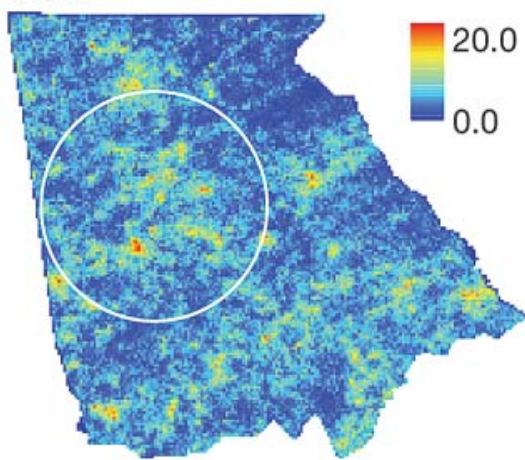

2002

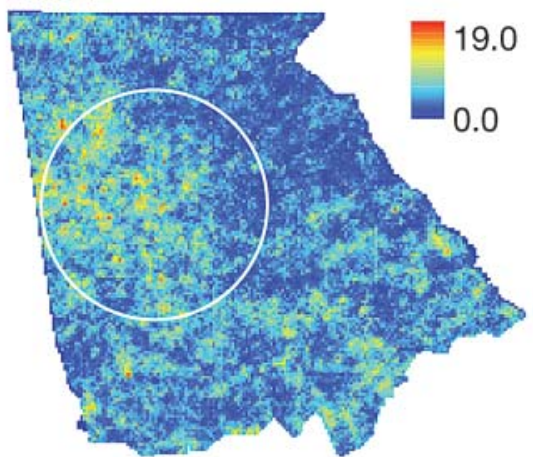

1994

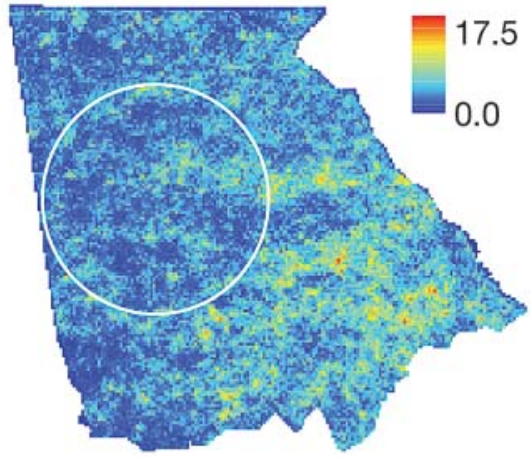

1997

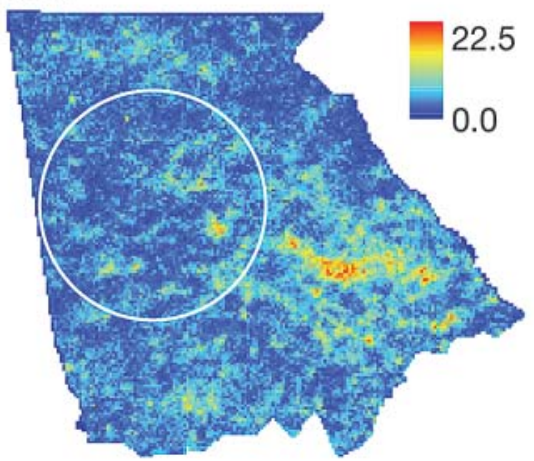

2000

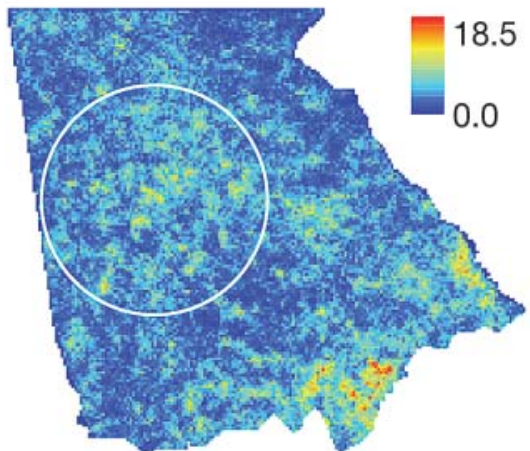

2003

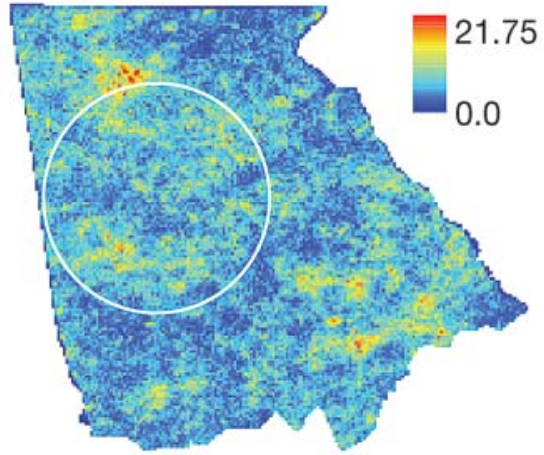

Fig. 5. Northern Georgia, USA. Annual flash density (flashes $\mathrm{km}^{-2} \mathrm{yr}^{-1}$ ). Main study area is denoted by white circle 
Table 1. Distribution of flashes and flash days by flash category (no. of flashes in a day) for zones of urban-augmented flash density

\begin{tabular}{|lcrrc|}
\hline City zone & $\begin{array}{c}\text { Flash } \\
\text { category }\end{array}$ & \multicolumn{2}{c}{$\begin{array}{c}\text { No. of } \\
\text { flashes (\%) }\end{array}$} & $\begin{array}{c}\text { No. of } \\
\text { flash days }\end{array}$ \\
\hline NE & $0-10$ & 74 & $(0.09)$ & 41 \\
& $11-100$ & 816 & $(1.04)$ & 153 \\
& $101-1000$ & 15257 & $(19.40)$ & 405 \\
& $1000-10000$ & 61099 & $(77.70)$ & 286 \\
Center & $>10000$ & 1386 & $(1.76)$ & 2 \\
& $0-10$ & 65 & $(0.08)$ & 47 \\
& $11-100$ & 810 & $(0.99)$ & 165 \\
& $101-1000$ & 16478 & $(20.19)$ & 434 \\
SW & $1000-10000$ & 62259 & $(76.29)$ & 298 \\
& $>10000$ & 2001 & $(2.45)$ & 2 \\
& $0-10$ & 77 & $(0.10)$ & 50 \\
& $11-100$ & 948 & $(1.22)$ & 156 \\
& $101-1000$ & 14007 & $(18.02)$ & 411 \\
& $1000-10000$ & 59211 & $(76.18)$ & 290 \\
& $>10000$ & 3478 & $(4.47)$ & 2 \\
\hline
\end{tabular}

positive flashes first appear around Atlanta's loop highway, and extend approximately $150 \mathrm{~km}$ downwind (eastward). The spatial extent of positive flash reductions relative to where they emerged indicates that urban pollutants modify cloud electrification over considerable distances. The western border of this zone of reduced positive polarity flashes was along Interstate Highway 75. This pattern suggests that pollution along the major corridors of automobile transportation modifies cloud electrification. Automobiles,
Table 2. Number of flash days (shared and unique) and associated flash counts among zones of urban-augmennted flash density. Shared flash days: $N=611$. Prod.: production

\begin{tabular}{|c|c|c|c|c|c|}
\hline \multirow[t]{2}{*}{ Location } & \multirow{2}{*}{$\begin{array}{l}\text { Total } \\
\text { days }\end{array}$} & \multicolumn{2}{|c|}{ Shared days } & \multicolumn{2}{|c|}{ Unique days } \\
\hline & & $\%$ & Prod. \% & $\mathrm{N}$ & Prod. \% \\
\hline East & 931 & 65.6 & 88.6 & 320 & 11.4 \\
\hline West & 906 & 67.4 & 92.2 & 295 & 7.8 \\
\hline South & 942 & 64.9 & 88.4 & 331 & 11.6 \\
\hline
\end{tabular}

particularly diesel engines, produce aerosols from fuel combustion that have the potential to alter precipitation patterns (see Givati \& Rosenfeld 2004). Dixon \& Mote (2003) also noted a linkage between highway proximity and the location of precipitation events influenced by UHI factors. The ongoing HEAT (Houston Environmental Aerosol Thunderstorm) Project in Houston, Texas (Orville et al. 2004) is expected to provide more detail about how aerosols influence lightning characteristics; its results will be useful for validating some of our hypotheses about the distribution and controls of positive polarity charges.

Intermediate-sized lightning events (100-10000 flashes) were mostly responsible for Atlanta's flash enhancement. Similar results have been found in several other North American cities (Wescott 1995, Steiger et al. 2002). Lower levels (1-10, and 10-100 flashes) did not exhibit any urban-rural flash differentiation, nor did the highest interval (>10 000 flashes). Atlanta's UHI does not appear to significantly increase the initiation of new flash events. Urban augmentation was more the result of enhanced production than any increase in the number of days with flashes. The high flash densities NE of Atlanta in Fulton, Dekalb, and Gwinnett counties accrued largely on days when flashes were also observed at locations upwind to the east and west of the city. These 2 findings have a consistent internal logic: the atmospheric instability on days when large flash outbreaks occur is likely to promote flash production over a wide area.

Dixon \& Mote (2003) postulated that greater UHI intensities do not necessarily yield more urban-initiated precipitation. Low-level moisture, as a source of atmospheric instability, is also necessary. Similarly, urban lightning modification may be suppressed in short-lived or shallow clouds, because more instability is required to lift water to the levels needed for flash

Fig. 6. Annual standard deviation of flash density 

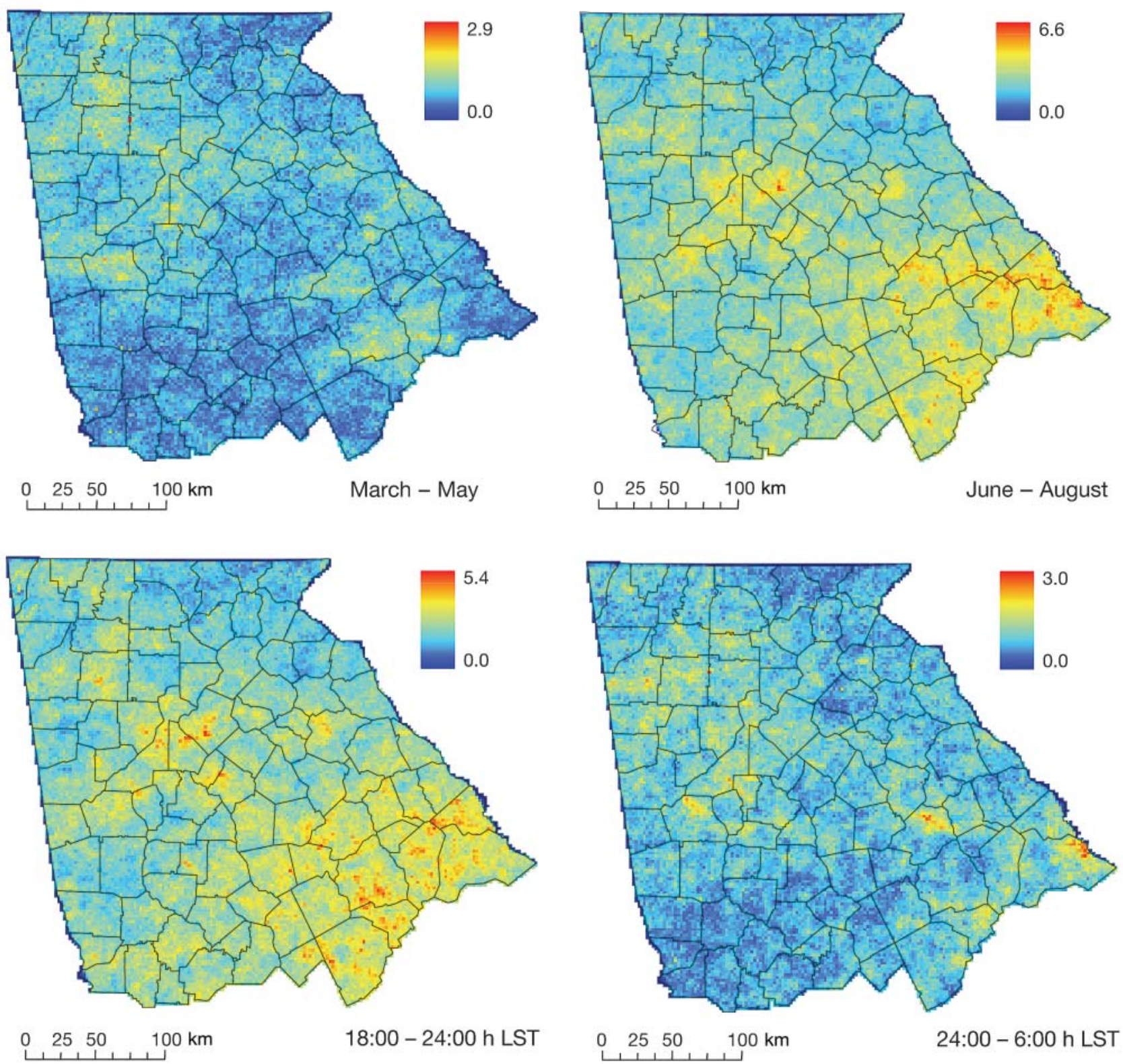

Fig. 7. Spring, summer, and diurnal patterns of flash density (flashes $\mathrm{km}^{-2} \mathrm{yr}^{-2}$ ). LST: Local standard time

production. Differences in the spatial and interval signatures of Atlanta flash augmentation support Dixon \& Mote's conclusions. Flash augmentation first appeared over the Atlanta central city at the 100-1000 flash interval. This may develop from the central city's greater heating potential, compared to the adjacent suburban heating nodes. Numerical simulation by Baik et al. (2001) found that less urban forcing is needed to trigger moist convection when the atmospheric setting is thermodynamically favorable.

Although flash day counts per $2 \times 2 \mathrm{~km}$ grid cell were higher in NE Atlanta (see Fig. 11), this zone experienced fewer calendar flash days overall (931) than the southern zone (942 d). This counterintuitive pattern arose from differences between zones in the spatial scale at which flashes accumulated. There are more flash days in NE Atlanta, but the flashes produced are recorded across many of the cells on the same date. In other words, the flash days recorded here influence a wider area, boosting day counts across all of the grid cells. To the south, flash days accrue over a smaller number of cells, thus keeping individual cell counts low but overall flash days high. This pattern corroborates the idea that larger storms, affecting a larger area, are responsible for urban flash augmentation.

Atlanta's flash augmentation is not unique within the Georgia Piedmont. There are neighboring peaks in flash production of similar intensity. For this reason, 


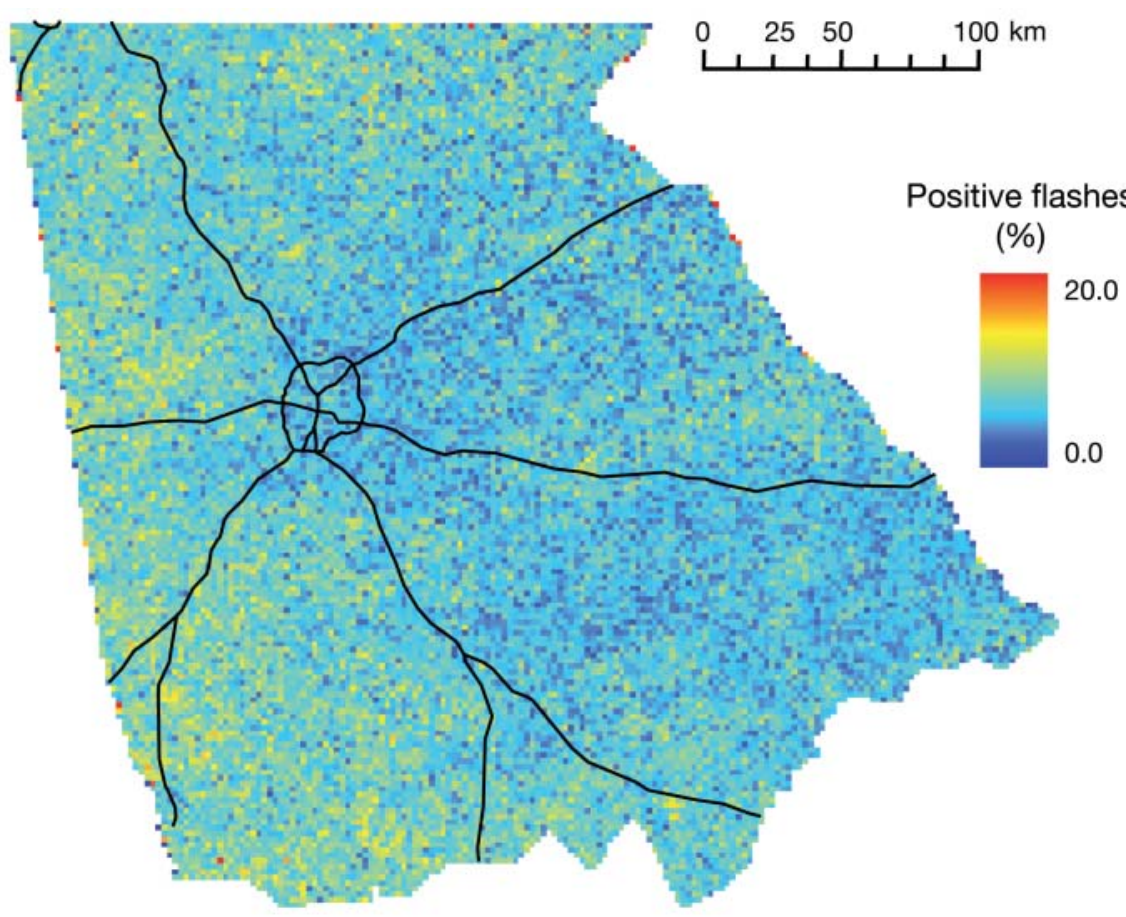

Fig. 8. Percentage of positive cloud-to-ground flashes

(see Fig. 3). This topographic change marks the transition between the Piedmont physiographic region to the north and the low-lying GulfAtlantic Coastal Plain to the south. Such local relief could enhance uplift of unstable maritime air masses. The development of quasi-stationary Piedmont fronts, which can produce severe weather, may also explain the enhanced flashes in this area. These fronts develop in the vicinity of the fall line through surface convergence indirectly coupled to the coastal front convergence further south (Businger et al. 1991, Bentley \& Stallins 2005).

In the case of the high flash densities in the NW corner of the state, the relative importance of topographic versus anthropogenic controls is ambiguous. There is anecdotal evidence of anomalous flash production in this sector. In 1997, the Federal Emergency Management Agency

more research is needed to ascertain the relative importance of urban versus non-urban modified lightning production in Atlanta and these other hotspots. Natural processes can be invoked as a causal mechanism for the flash anomaly in eastern central Georgia. A prominent topographic break, known as the fall line, runs across Georgia from Augusta near the South Carolina border to Columbus on the border with Alabama

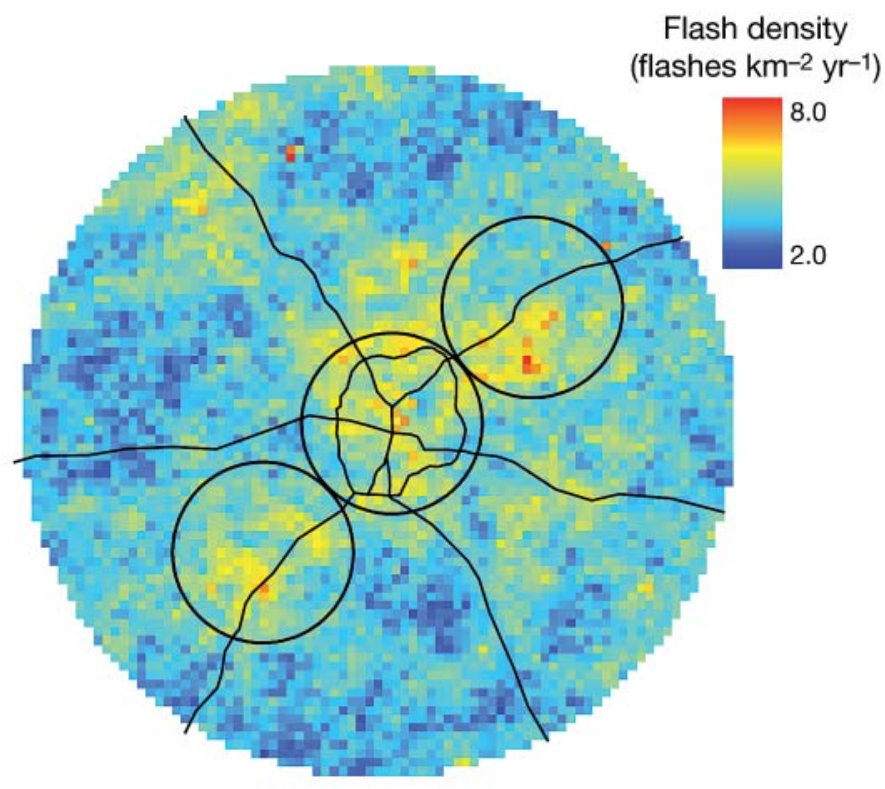

Fig. 9. Annual average flash density within $80 \mathrm{~km}$ of downtown Atlanta. Circles: zones of enhancement spent $\$ 260000$ to install lightning protection equipment in Bartow County to address the large number of flashes striking a complex of governmental buildings. Within a 2 mo period in 1997, a 5-fold increase of flashes was recorded (FEMA 1998). The anomaly over Coweta County, SW of Atlanta, is also of undetermined origin; flash density standard deviation values suggests that high flash densities here were the product of a few storms.

\section{CONCLUSIONS}

The Atlanta metropolitan area experiences enhanced cloud-to-ground lightning production. Maxima in annual average flash density (6 to 8 flashes $\mathrm{km}^{-2}$ $\mathrm{yr}^{-1}$ ) developed in heavily suburbanized Gwinnett County NE of Atlanta. Meoscale modeling of urbaninduced convection over Atlanta (Craig \& Bornstein 2002) and an analysis of the region's historical precipitation record in light of land-use changes (Diem \& Mote 2005) also identified increased convection to the north and east of downtown Atlanta. Insofar as these studies document an anthropogenic signal in Atlanta's weather and climate, land-use changes do not appear to initiate flashes as much as they enhance favorable conditions for flash production.

The number and patterning of flashes in production intervals $(1-10,11-100 \ldots)$ may be a proxy for gauging the degree of urban augmentation among different 

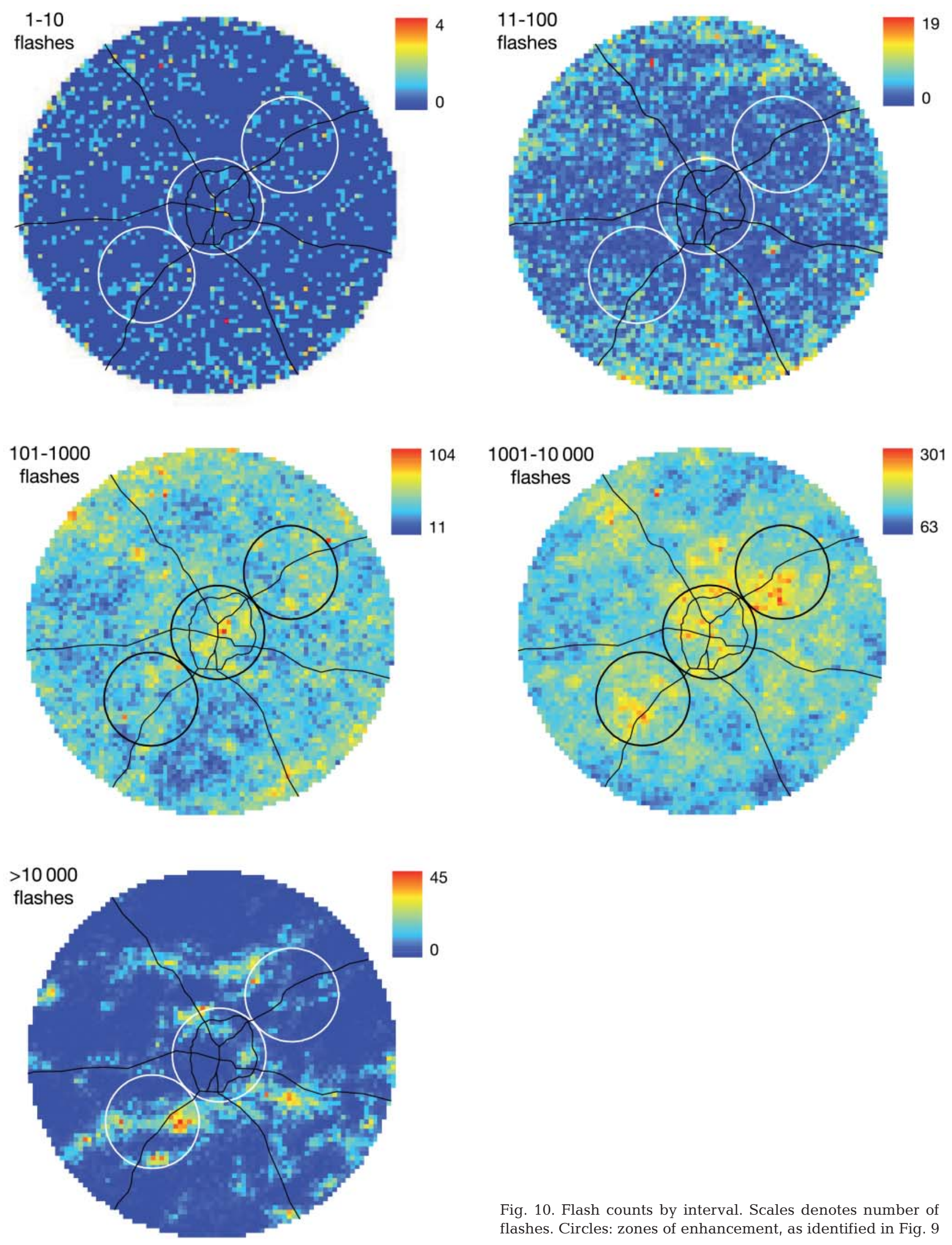

Fig. 10. Flash counts by interval. Scales denotes number of flashes. Circles: zones of enhancement, as identified in Fig. 9 


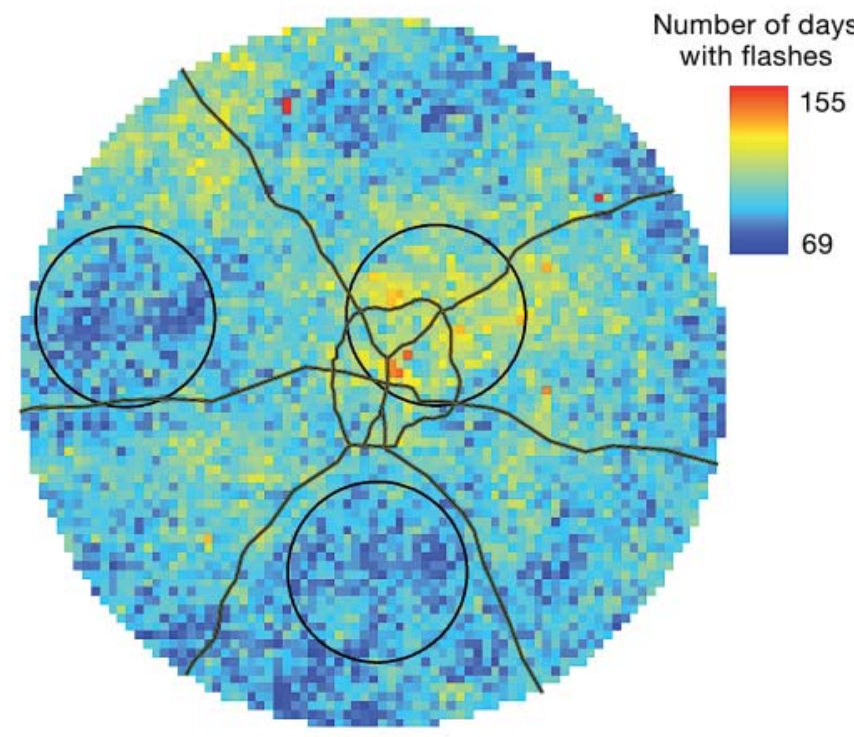

Fig. 11. Number of days on which flashes were observed over the period 1992-1993. Circles: central zone of enhancement and outlying zones with lowered levels

locations. For example, at locations with greater UHI effects and aerosol concentrations, flash augmentation may develop at lower flash intervals. With greater local heating and aerosol concentrations, the threshold at which the smaller, aerosol-influenced water droplets can be transported to freezing levels is lowered. In comparisons among cities, a given level of instability would result in more flash production at lower flash intervals for a city with higher UHI effects and aerosol concentrations. A standardized study of city-to-city variability in the relationships among local urban heating, aerosol concentrations, and interval-defined measures of instability and flash production may be a practical avenue for elucidating the processes underlying urban flash modification.

Although our study documents enhanced flash production around Atlanta and suggests relations to anthropogenic causes, the quantification of urban versus non-urban factors will require, among others, an analysis of individual storm tracks as they pass over or near the Atlanta area. More detail could also be acquired by evaluating the correspondence between flashes and specific land-use categories and by assessing flash patterns by thunderstorm type. Our findings could be also be strengthened by establishing the degree of statistical randomness in the flash patterns for the Atlanta region. Given that there are locations near Atlanta that have similarly high flash densities, more attention should be placed on the statistical significance of the overall distribution of flashes. Local elevational controls and upslope-driven convection in the vicinity of Atlanta should also be considered as potential factors contributing to flash enhancement.
Acknowledgements. This study was supported by a National Science Foundation Grant (BCS - 0241062) to J.A.S. and M.L.B.

\section{LITERATURE CITED}

Areitio J, Ezcurra A, Herrero I (2001) Cloud-to-ground lightning characteristics in the Spanish Basque Country area during the period 1992-1996. J Atmos Solar Terrest Phys 63:1005-1015

Arnfield AJ (2003) Two decades of urban climate research: a review of turbulence, exchanges of energy and water, and the urban heat island. Int J Climatol 23:1-26

ARC (2003) The changing Atlanta region: new from Census 2000. Atlanta Regional Commission, Atlanta, GA. Available at: www.atlantaregional.com/regionaldata/Changing AtlantaRegion.pdf

Baik JJ, Kim YH, Chun HY (2001) Dry and moist convection forced by an urban heat island. J Appl Meteorol 40: 1462-1475

Bentley ML, Stallins JA (2005) Climatology of cloud-toground lighhtning in Georgia, USA, 1992-2003. Int J Climatol 25:1979-1996

Bornstein R, Lin QL (2000) Urban heat islands and summertime convective thunderstorms in Atlanta: three case studies. Atmos Environ 34:507-516

Businger S, Bauman WH, Watson GF (1991) The development of the Piedmont front and associated outbreak of severe weather on 13 March 1986. Mon Weather Rev 119: $2224-2251$

Changnon SA (2001) Assessment of historical thunderstorm data for urban effects: the Chicago case. Clim Change 49:161-169

Changnon SA, Semonin RG, Huff FA (1976) Hypothesis for urban rainfall anomalies. J Appl Meteorol 15:544-560

Craig KJ, Bornstein RD (2002) MM5 simulation of urban induced convective precipitation over Atlanta. Preprint Vol., 4th Am Meteorol Soc Symp Urban Environment, American Meteorological Society, Boston, MA, p 5-6. Available at: http://www.met.sjsu.edu/faculty/bornstein/ atlanta/mm5-ken-atlanta-2002.pdf

Cummins KL, Murphy MJ, Bardo EA, Hiscox WL, Pyle RB, Pifer AE (1998) A combined TOA/MDF technology upgrade of the US National Lightning Detection Network. J Geophys Res Atmos 103:9035-9044

Curran EB, Holle RL, Lopez RE (2000) Lightning casualties and damages in the United States from 1959 to 1994. J Clim 13:3448-3464

Diem JE, Brown DP (2003) Anthropogenic impacts on summer precipitation in central Arizona, USA. Prof Geogr 55:343-355

Diem JE, Mote TL (2005) Interepochal changes in summer precipitation in the southeastern United States: evidence of possible urban effects near Atlanta, Georgia. J Appl Meteorol 44:717-730.

Dixon PG, Mote TL (2003) Patterns and causes of Atlanta's urban heat island-initiated precipitation. J Appl Meteorol 42:1273-1284

ESRI (2004) ArcGIS: Release 9.0. Environmental Systems Research Institute, Redlands, CA

FEMA (1998) Bartow County lightning project funding exceeds \$260,000. Federal Emergency Management Agency. Available at: www.fema.gov/regions/iv/1998/ r4_048.shtm

Gauthier ML, Peterson WA, Carey LD, Orville RE (2005) Dissecting the anomaly: a closer look at the documented 
urban enhancement in summer season ground flash densities in and around the Houston area. Geophys Res Lett 32(10) Art No. L10810

Givati A, Rosenfeld D (2004) Quantifying precipitation suppression due to air pollution. J Appl Meteorol 43: 1038-1056

Huff FA, Changnon SA (1973) Precipitation modification by major urban areas. Bull Am Meteorol Soc 54:1220-1232

Kalnay E, Cai M (2003) Impact of urbanization and land-use change on climate. Nature 423:528-531

Livingston ES, Nielsen-Gammon JW, Orville RE (1996) Climatology, synoptic assessment, and thermodynamic evaluation for cloud-to-ground lightning in Georgia: a study for the 1996 Summer Olympics. Bull Am Meteorol Soc 77:1483-1495

Lo CP, Yang XJ (2002) Drivers of land-use/land-cover changes and dynamic modeling for the Atlanta, Georgia Metropolitan Area. Photogramm Eng Remote Sens 68:1073-1082

MacGorman DR, Rust WD (1998) The electrical nature of storms. Oxford University Press, New York

Marshall CH, Pielke RA, Steyaert LT (2004) Has the conversion of natural wetlands to agricultural land increased the incidence and severity of damaging freezes in south Florida? Mon Weather Rev 132:2243-2258

Mullen L (1999) Welcome to the thunderdome: Atlanta's urban heat alters weather patterns. NASA Science News. Available at: http://science.nasa.gov/newhome/headlines/ essd26apr99 \% 5F 1 .htm

Naccarato KP, Pinto O, Pinto I (2003) Evidence of thermal and aerosol effects on the cloud-to-ground lightning density and polarity over large urban areas of southeastern Brazil. Geophys Res Lett 30

Oke TR (1973) City size and urban heat island. Atmos Environ 7:769-779

Orville RE, Huffines GR (2001) Cloud-to-ground lightning in the United States: NLDN results in the first decade, 19891998. Mon Weather Rev 129:1179-1193

Orville RE, Huffines G, Nielsen-Gammon J, Zhang RY and 5 others (2001) Enhancement of cloud-to-ground lightning over Houston, Texas. Geophys Res Lett 28:2597-2600

Orville RE, Zhang R, Nielsen-Gammon J, Collins D, Carey L, Stuart A, Ely B, Steiger S (2004) Houston Environmental Aerosol Thunderstorm (HEAT) Project. Department of Atmospheric Sciences, Texas A\&M University, College Station, TX. Available at: www.met.tamu.edu/ciams/heat/

Pielke RA (2002) Overlooked issues in the US national climate and IPCC assessments. Clim Change 52:1-11

Pinto I, Pinto O, Gomes M, Ferreira NJ (2004) Urban effect on the characteristics of cloud-to-ground lightning over Belo Horizonte-Brazil. Anal Geophys 22:697-700

Quattrochi D, Luvall J, Estes M, Lo CP and 6 others (1998) Project Atlanta (Atlanta land use analysis: temperature

Editorial responsibility: Daniel J. Leathers, Delaware, USA and air quality): a study of how urban landscape affects meteorology and air quality through time. Preprint Vol., 2nd Am Meteorol Soc Urban Environment Conf, American Meteorological Society, Boston, MA p 104-107

Rosenfeld D, Lensky IM (1998) Satellite-based insights into precipitation formation processes in continental and maritime convective clouds. Bull Am Meteorol Soc 79: $2457-2476$

Rozoff CM, Cotton WR, Adegoke JO (2003) Simulation of St. Louis, Missouri, land use impacts on thunderstorms. J Appl Meteorol 42:716-738

Saunders CPR (1993) A review of thunderstorm electrification processes. J Appl Meteorol 32:642-655

Seity Y, Soula S, Tabary P, Scialom G (2003) The convective storm system during IOP 2a of MAP: cloud-to-ground lightning flash production in relation to dynamics and microphysics. Q J R Meteorol Soc 129:523-542

Shepherd JM (in press) A review of current investigations of urban-induced rainfall and recommendations for the future. Earth Inter

Shepherd JM, Pierce H, Negri AJ (2002) Rainfall modification by major urban areas: observations from spaceborne rain radar on the TRMM satellite. J Appl Meteorol 41:689-701

Soriano LR, de Pablo F (2002) Effect of small urban areas in central Spain on the enhancement of cloud-to-ground lightning activity. Atmos Environ 36:2809-2816

Stallins JA (2002) An overlooked source of weather-related property damage in the southeast: lightning losses for Georgia, 1996-2000. Southeast Geogr 42(2): 296-301

Steiger SM, Orville RE (2003) Cloud-to-ground lightning enhancement over southern Louisiana. Geophys Res Lett 30(19) Art No. 1975

Steiger SM, Orville RE, Huffines G (2002) Cloud-to-ground lightning characteristics over Houston, Texas: 1989-2000. J Geophys Res Atmos 107(D11) Art. No. 4117

Stone B, Rodgers MO (2001) Urban form and thermal efficiency - how the design of cities influences the urban heat island effect. J Am Plann Assoc 67:186-198

Watson AI, Holle RL (1996) An 8-year lightning climatology of the southeast United States prepared for the 1996 Summer Olympics. Bull Am Meteorol Soc 77:883-890

Weber AH, Buckley RL, Parker MJ, Brown ME (2001) Wind speed and direction analysis for a group of Southeast surface stations. US Department of Energy and Washington Savannah River Company, Augusta, GA. Available at: http://sti.srs.gov/fulltext/ms2001695/ms2001695.html

Westcott NE (1995) Summertime cloud-to-ground lightning activity around major midwestern urban areas. J Appl Meteorol 34:1633-1642

Yang X, Lo CP (2002) Using a time series of satellite imagery to detect land use and land cover changes in the Atlanta, Georgia metropolitan area. Int $\mathrm{J}$ Remote Sens 23: $1775-1798$

Submitted: January 23, 2005; Accepted: December 7, 2005

Proofs received from author(s): February 17, 2006 